\title{
Devonian micritic limestones used in the historic production of Prague hydraulic lime ('pasta di Praga'): characterization of the raw material and experimental laboratory burning
}

\author{
P. Kozlovcev凶, R. Přikryl \\ Charles University in Prague, (Prague, Czech Republic) \\ $\triangle$ p.kozlovcev@seznam.cz
}

Received 17 September 2014
Accepted 27 January 2015
Available on line 21 J uly 2015

\begin{abstract}
The Devonian micritic limestones from the Prague Basin (Barrandian area, Bohemian Massif, Czech Republic), which were the primary raw material used for natural hydraulic lime burned in Prague, exhibit a feebly to eminently hydraulic character. Based on a laboratory experimental study, the burned product is composed of dominant free-lime $(\mathrm{CaO})$ and/or portlandite $\left(\mathrm{Ca}(\mathrm{OH})_{2}\right)$, larnite-belite (bicalcium silicate $\left.2 \mathrm{CaO} . \mathrm{SiO}_{2}\right)$, and quartz $\left(\mathrm{SiO}_{2}\right)$ - i.e. phases formed due to the decomposition of carbonate and quartz, present in the original limestones. Proportions of the newly formed phases depend on: the composition of the raw material, maximum burning temperature (the highest amount of larnite-belite appearing at a burning temperature of $1200{ }^{\circ} \mathrm{C}$ ), and the granulometry of the experimental batches (a coarsely-ground batch exhibited a higher amount of larnitebelite compared to the finely-ground one). The presence of minor phyllosilicates in the raw material contributed to the formation of gehlenite, brownmillerite, wollastonite, calcium aluminate, and/or spurrite.
\end{abstract}

KEYWORDS: Limestone; Lime; Bicalcium silicate; Scanning Electron Microscopy (SEM); X-ray Diffraction (XRD)

Citation/Citar como: Kozlovcev, P.; Prrikryl, R. (2015) Devonian micritic limestones used in the historic production of Prague hydraulic lime ('pasta di Praga'): characterization of the raw material and experimental laboratory burning. Mater. Construcc. 65 [319], e060. http://dx.doi.org/10.3989/mc.2015.06314.

RESUMEN: Calizas micríticas devonianas utilizadas en históricamente en la producción de la cal hidráulica de Praga ('pasta di Praga'): caracterización de las materias primas y procedimiento experimental de calcinación en laboratorio. Las calizas micríticas devonianas provenientes de la Cuenca de Praga (área de Barrand, macizo de Bohemia, República checa) que fueron la principal materia prima utilizada para la producción de la cal hidráulica natural calcinada en Praga, presentan un carácter hidráulico desde débil hasta alto. El estudio experimental de laboratorio, ha determinado que el producto calcinado está compuesto de cal viva $(\mathrm{CaO})$ como componente predominante y/o cal hidratada $\left(\mathrm{Ca}(\mathrm{OH})_{2}\right)$, larnita-belita (silicato bicálcico $\left.2 \mathrm{CaO} . \mathrm{SiO}_{2}\right)$ y cuarzo $\left(\mathrm{SiO}_{2}\right)$ - es decir, fases formadas como resultado de la descomposición de carbonato y cuarzo presentes en las calizas originales. Las proporciones de las nuevas fases formadas dependen de: la composición de la materia prima, temperatura máxima de calcinación (la mayor cantidad de larnita-belita se produce a la temperatura de calcinación de $1200{ }^{\circ} \mathrm{C}$ ), y la granulometría de las muestras (las muestras con granulometría gruesa presentaron mayor cantidad de belita que las de granulometría fina). La presencia de bajas cantidades de filosilicatos en la materia prima contribuyó a la formación de gehlenita, brownmillerita, wollastonita, calcio aluminoso, y/o spurrita.

PALABRAS CLAVE: Caliza; Cal; Silicato bicálcico; Microscopía Electrónica de Barrido (MEB); Difracción de rayos $\mathrm{X}(\mathrm{DRX})$

Copyright: (C) 2015 CSIC. This is an open-access article distributed under the terms of the Creative Commons Attribution-Non Commercial (by-nc) Spain 3.0 License. 


\section{INTRODUCTION}

Despite the dominant use of Ordinary Portland Cement (OPC) as almost the exclusive hydraulic binder in the modern construction industry, the increased interest in the production and application of alternative hydraulic binders (natural hydraulic lime, natural cement) can be seen during the past decades $(1,2)$. This is caused not only by their needed use in the restoration of historical monuments (3-10), but also due to their lower environmental impact during their production and use compared to OPC (11). Natural hydraulic lime (NHL) and/or natural cement $(\mathrm{NC})$ are often required in restoration practice due to their favourable composition $(12,13)$ and physical properties (14) that make them more compatible with traditional construction materials (e.g. natural stone) than is OPC (15). The search for corresponding raw materials, the technology of their production, and the modes of utilisation of $\mathrm{NHL}$ and/or NC is also motivated by the longevity of ancient structures built of them (16-21).

The former lands of the Czech crown (specifically Bohemia, which makes up a major part of the current Czech Republic) are known to have produced diverse types of inorganic constructional binders over many centuries (22). Hydraulic binders belonging to the hydraulic lime series were so well known in the Middle ages that some of their resources and favourable properties were felt worth being mentioned in the general philosophical treatises of that time (cf. Liber naturalis in Miscellanea Historica regni Bohemiae, i.e. "Miscellany of Bohemian History" written by the Czech writer and Jesuit priest Bohuslav Balbín, published in 6 volumes in Prague, 1679-1687). The excellent quality of hydraulic binders from Prague's surroundings, and their international reputation was then reflected in the denomination of moderate to eminent hydraulic binders as "pasta di Praga" (a term introduced by Italian stonemasons working during the Baroque in Prague and Bohemia, $c f$. Balbín, op. cit.). As in many countries, non-standardised production of various hydraulic binders was gradually replaced by Portland cement-based binders at the turn of $19 / 20^{\text {th }} \mathrm{c}$.

Despite detailed lithostratigraphical and/or palaeontological study of these limestones during the past decades $(23,24)$, materials research in relationship to the composition and quality of the burned materials is still missing. The current study aims to explore the mineralogical composition and petrographic character of one of the main types of these Devonian limestones - the so called Dvorce-Prokop Limestones - and the influence of mineralogical/petrographical parameters on the phase composition of the burned product - a NHL and/or NC. Laboratoryscale research allowed us to establish a more precise link between a certain peak temperature of burning to gradual changes of newly formed phases.

\section{GEOLOGICAL SETTING}

The abandoned limestone quarries from where our samples were taken are situated in the Prague Basin, which represents the largest Neoproterozoic - Lower Palaeozoic sedimentary basin of the Bohemicum (Teplá-Barrandian) terrane in the centre of the Bohemian Massif (Figure 1A). Primarily, Lower Palaeozoic marine sediments (24) were deposited in this rift-like depression (25), elongated in the SW-NE direction (Figure 1B); its NE termination outcrops at the SW margin of Prague. The complete sedimentary record from the Silurian up to the Middle Devonian is extraordinarily fossiliferous and thus makes this area - also known as the Barrandian area - one of the most famous palaeontological regions of the world $(23,24)$. Sedimentary fill of the Prague Basin was affected by remarkably diverse tectonic activity, ranging from germanotype to alpinotype features, which can be partly explained by a segmented heterogeneous Upper Proterozoic basement $(27,28)$ composed of metamorphic rocks of Teplá-Barrandian terrane (29). Extensive sedimentary activity in a passive-margin setting occasionally has been accompanied with volcanism and synsedimentary deformation of the Basin fill (24), followed by burial and deformation of the whole Bohemicum as a part of Armorican terrane assemblage during the Variscan orogeny, specifically during the Frasnian to late Carboniferous (30).

The lithology of the Prague Basin is characterised by the presence of various sedimentary rocks (shales, siltstones, sandstones, limestones, silicites/ cherts), locally accompanied with syngenetic volcanic rocks and volcanoclastics sediments. In contrast to dominant shale deposition in the Lower Silurian, eustatic movements caused basin shallowing during the Upper Silurian (31), specifically in the Lower/ Middle Devonian (32), which favoured the deposition of various types of limestone, most of them of industrial importance. Sedimentation in an offshore environment is marked by the presence of dominant bioclastic (shallower parts of the basin representing a high energy environment) and micritic (deeper parts of the basin, pelagic conditions) facies.

\subsection{Sampling site and a short history of its exploitation}

The sampling site is located in the southern part of Prague (Prague 4 district, a local area called Bráník, incorporated into Prague in 1949) where large outcrops (faces of a historic abandoned quarry) of the Lower Devonian (Pragian stage) rocks can be found. The area of the abandoned quarry, located on the right bank of the Vltava River, has been protected since 1986 as 'Bráník Rocks Natural Monument'. The exposed quarry face (Figure 2) is over $400 \mathrm{~m}$ long and about $50 \mathrm{~m}$ high. The rocks exposed in this quarry belong to the deep-water basin facies 


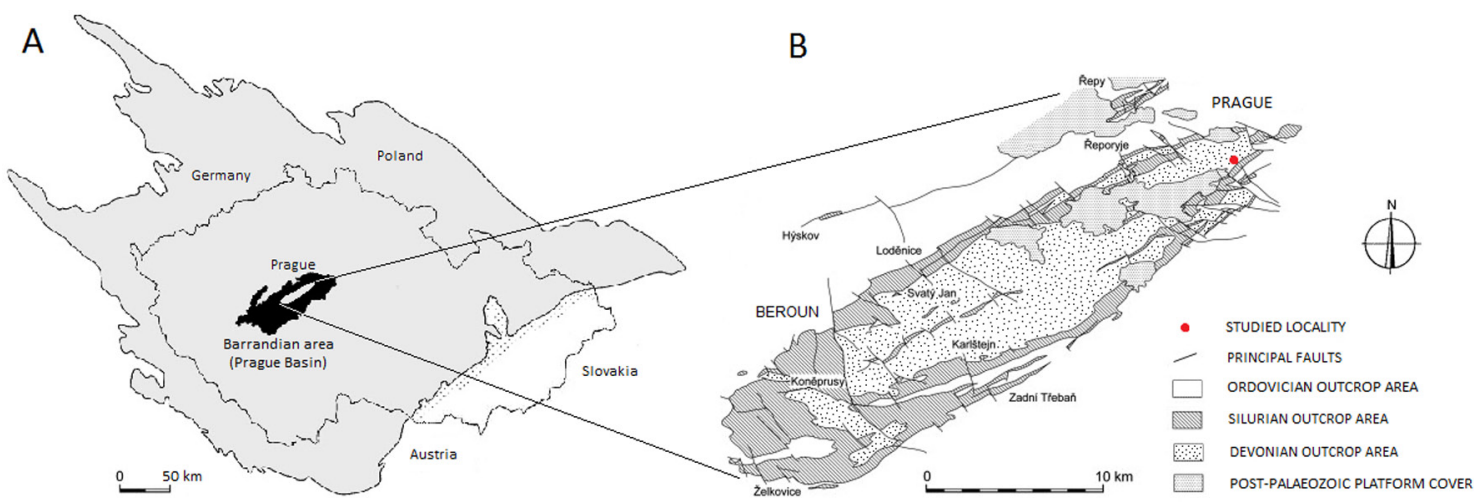

Figure 1. Position of Palaeozoic sediments of Prague Basin within the Bohemian Massif (A) and a geological map of the central part of the Prague Basin (modified after (26)) with marked sampling site (B).

of Devonian micritic limestones (mudstones and/ or wackstones sensu Dunham (33)), lithofacially known as Dvorce-Prokop Limestones).

The beginnings of exploitation of limestones in this area is probably connected with the extensive construction activity of an expanding Prague in the mid $14^{\text {th }}$ c. (during the reign of the Czech King and Emperor of the Holy Roman Empire, Charles IV Luxembourg). Exploitation and use of these limestones during the $14^{\text {th }} \mathrm{c}$. cannot be proven from any written record but only through the material evidence, which is based on the analysis of mortars and 'concretes' from well-dated structures such as the Charles Bridge in Prague, for which the local NHL was used (34). However, written records, which are younger, document a well-developed exploitation at the site in the $17^{\text {th }}$ c. (cf. Balbín, op. cit.), and specifically in the $18^{\text {th }} \mathrm{c}$. when the first collected Lower Palaeozoic fossils in the Prague Basin were described by Jesuit priest and philosopher Zeno

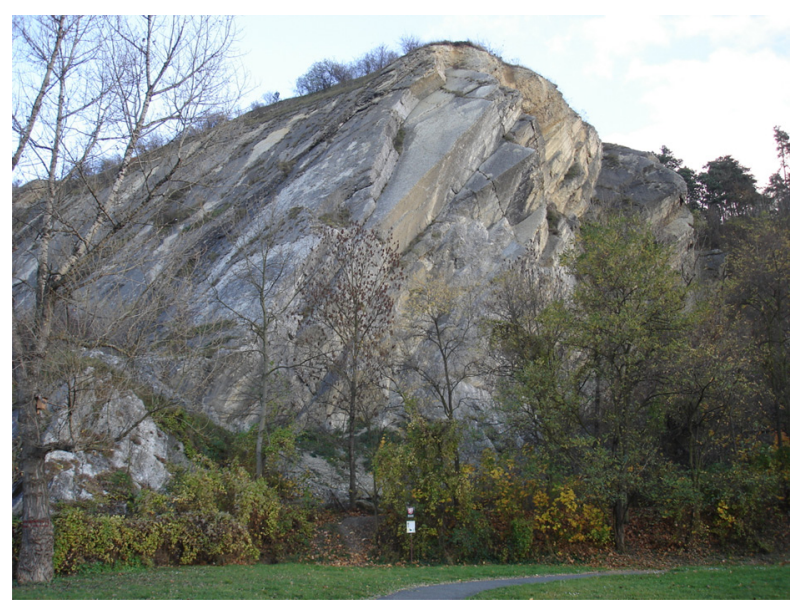

FIGURE 2. General view of the southern part of the abandoned historic quarry in the Podolí district (southern part of Prague).

Extensive exploitation of moderately to eminently hydraulic limestones from the 1860s until the 1920s destroyed all signs of earlier quarrying $\left(14^{\text {th }}-18^{\text {th }} \mathrm{c}\right.$.).
(35), based on his research in this specific quarry. The most extensive palaentological research of the area had been done by J. Barrande and J.M. Schary in the $19^{\text {th }} \mathrm{c}$. (31). Exploitation of limestones continued throughout the entire $19^{\text {th }} \mathrm{c}$. at this locality; the produced hydraulic lime (also Portland-like cement from about 1870s) was used for hydraulic structures (bridges, embankments, etc.) in Prague and Bohemia. The quarry was left abandoned in 1928. The limekilns, built in the 1860 s, were destroyed then and the whole area was urbanized. However, during the late 1930s and early 1940s, several galleries were excavated into the rock mass of the abandoned quarry with the aim to establish an underground factory during the Second World War (31).

\section{MATERIAL AND METHODS}

\subsection{Samples}

The experimental material was obtained from four levels of the Dvorce-Prokop Limestone unit (Figure 3), recently accessible in the exposed southern part of the abandoned quarry (Figure 2). Stratigraphically, all samples belong to the Lower Devonian (stage Pragian) limestones, locally known as Dvorce-Prokop Limestones (denominated as Bráník Limestones in older literature). Despite their close position within the same quarry, they show some differences in colour (Figure 4), granulometry, and degree of surface weathering. These minor variations in appearance reflects changes in composition as will be documented later in this paper.

Following the macroscopically observable differences, 4 major types of limestones (Figure 4) were distinguished by the authors. For each type, from 10 to $15 \mathrm{~kg}$ of fragmentary material was sampled in the abandoned quarry, and subjected to the analytical and experimental study as described below. 

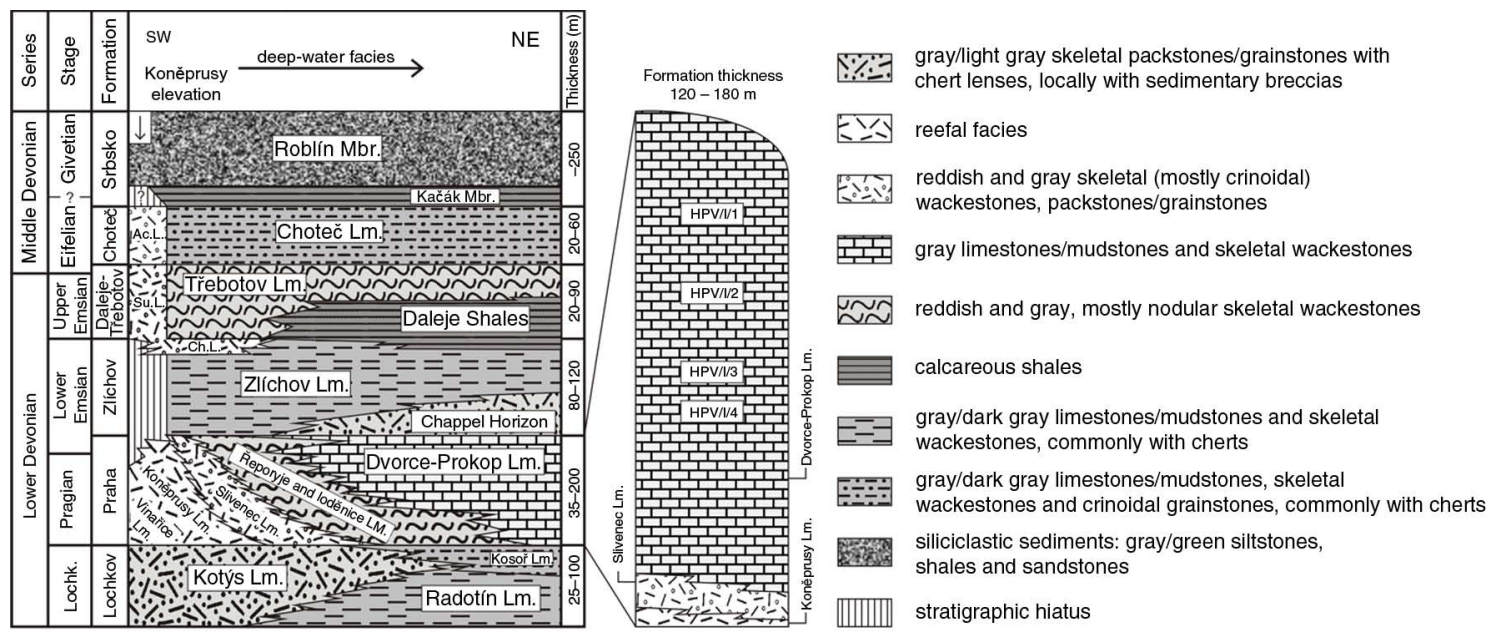

Lochk. - Lochkovian, Ch.L. - Chýnice Limestone, Su.L. - Suchomasty Limestone, Ac.L. - Acanthopyge Limestone, Lm. - Limestone, Mbr. - Member

FIgure 3. Lower and Middle Devonian lithostratigraphy of the Prague Basin (modified by Chlupáč (23)), and a simplified lithological profile through the Bráník rocks showing the approximate position of levels at which the experimental material was sampled.

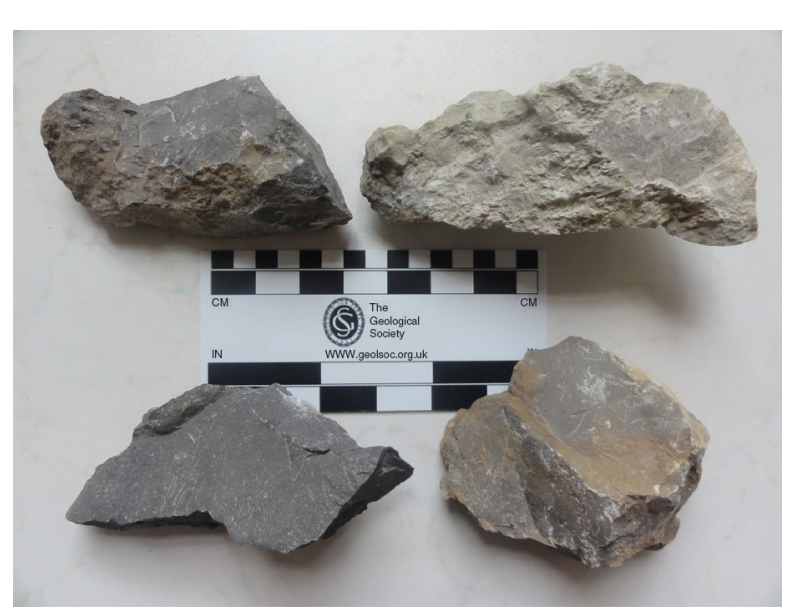

FIGURE 4. Macroscopic character of the experimental material employed in this study. From top left sample $\mathrm{HPV} / \mathrm{I} / 1, \mathrm{HPV} / \mathrm{I} / 2, \mathrm{HPV} / \mathrm{I} / 3$, and $\mathrm{HPV} / 1 / 4$.

\subsection{Petrographical and facial analyses}

After a brief macroscopic description of the raw material (unburnt limestone) hand specimens, a major part of petrographic research was conducted on the micro-scale using thin section study using a conventional optical microscope (Leica DMLP), supplemented with a cathodoluminiscence (CL) study. Observations of thin sections with an optical microscope provided the possibility of an overall description of the rock microfabric (basic qualitative data on present phases, their sizes, shapes and mutual relationships, distinguishing of bioclasts); however, the extremely fine-grained character of the rocks studied prohibited any sound quantification of modal composition and/or characterisation of minor components by the use of optical microscopy.
Also, the predominance of the fine-grained micritic carbonate component prevented the search for some specific features in the visible light mode. Some of the features were further studied by using a CL study employing 'cold' cathode type CCI $8200 \mathrm{Mk} 4$ coupled with a Leica DMLP optical microscope. These observations were performed under the following conditions: beam current $300 \mu \mathrm{A}$, electron energy $15-18 \mathrm{kV}$. Microphotographs documenting typical CL colours and patterns were captured with a Canon digital camera coupled with the optical microscope.

The extremely fine-grained character of the studied rocks, and the inability to conduct any quantitative analysis within an ordinary optical microscope, lead to the adoption of scanning electron microscopy with energy dispersive spectrometry (SEM/EDS) of polished, carbon-coated thin sections. These measurements were performed using a Tescan Vega instrument, with an Oxford Instruments LINK ISIS 300 energy-dispersive analytical system under the following conditions: beam current $0.8 \mathrm{nA} ; 180 \mathrm{~s}$ counting time; and a $20-30 \mathrm{kV}$ accelerating voltage. A 53 Minerals Standard Set \#02753-AB (SPI Supplies) was used for the standard quantitative calibration. SEM/EDS was also employed to obtain X-ray scans of representative areas (each about $1 \mathrm{~mm}^{2}$ ) on which the quantitative analysis (specifically modal composition) was performed.

\subsection{Analysis of non-carbonate phases}

Based on the chemical analyses, as described below, a non-carbonate component makes up an important part of the studied limestones. Their extremely fine-grained nature and relatively homogeneous distribution within the micritic carbonate 
matrix make their microscopic examination impossible (especially in an optical microscope). For this reason, phase analysis of non-carbonate phase was primarily performed by powder X-ray diffraction (XRD) of the insoluble residue. This was obtained by leaching off the carbonates, using a $1 \mathrm{M}$ solution of $\mathrm{HCl}$ and/or $\mathrm{CH}_{3} \mathrm{COOH}$ over a period of 12 hours. The samples were then centrifuged and washed in distilled water in order to remove water soluble salts (especially chlorides). After the settling of the insoluble residues, the excessive water was filtered through a filter paper on a laboratory suction device. The solid matter was then dried to a constant weight.

Dried insoluble residues were analysed by powder XRD using a PANalytical X'Pert Pro diffractometer equipped with a monochromator with $\mathrm{X}^{\prime}$ Celerator multichannel detectors. The measurement conditions were as follows: $\mathrm{Cu}$ cathode $\alpha, 40 \mathrm{kV}, 30 \mathrm{~mA}$, measuring step $0.05^{\circ} / 200$ seconds, angle $2.99-70^{\circ} 2 \Theta$. The resulting diffractograms were processed and evaluated using X'Pert High Score 1.0d software and the JCPDS PDF-2 database.

\subsection{Chemical analyses}

Prior to experimental burning, the studied limestones were also examined for their chemical composition. Major elements were determined by classical wet chemical analysis (36) of samples milled to analytical fineness. From the analytical data, the total percentage of carbonates was determined. Further, theoretical quantitative phase composition (normative minerals) was computed following the MINLITH algorithm $(37,38)$. The MINLITH procedure is similar to the calculation of normative minerals using the CIPW norm in magmatic petrology.

Data from the chemical analysis also served for the evaluation of the hydraulicity of the studied materials. This property can be computed by using so called hydraulic index (HI) as suggested by Spalding (39) [1]:

$$
\mathrm{HI}=\frac{\mathrm{SiO}_{2}+\mathrm{Al}_{2} \mathrm{O}_{3}}{\mathrm{CaO}}
$$

The resulting value is dimensionless and the scale for HI is: $0.1-0.2$ (feebly hydraulic materials), 0.2-0.4 (moderate hydraulic materials) and 0.4-1 (for eminently hydraulic materials) (39).

Cementation index (CI) was proposed by Eckel (40) as [2]:

$$
\mathrm{CI}=\frac{2.8 \cdot \mathrm{SiO}_{2}+1.1 \cdot \mathrm{Al}_{2} \mathrm{O}_{3}+0.7 \cdot \mathrm{Fe}_{2} \mathrm{O}_{3(t o t)}}{\mathrm{CaO}+1.4 \cdot \mathrm{MgO}}
$$

The scale for CI is: $0.3-0.5$ (feebly hydraulic materials), 0.5-0.7 (moderate hydraulic materials) and 0.7-1.1 (for eminently hydraulic materials) (40).

\subsection{Experimental burning and study of burned product}

Experimental burning was performed in a laboratory furnace (type 0612 by Clasic Co.) by using two different experimental batches: (1) the finely-ground batch obtained by milling (particle size ranging from 100 to $500 \mu \mathrm{m}$ ), and (2) the coarsely-ground batch crushed to a particle size of $1.25-3 \mathrm{~mm}$. Each of these sample sets was subdivided into 8 batches that were burned, reaching a peak temperature between $850{ }^{\circ} \mathrm{C}$ to $1200^{\circ} \mathrm{C}$ in $50{ }^{\circ} \mathrm{C}$ steps. The temperature was elevated each $100^{\circ} \mathrm{C}$ in about 10 minutes, and the peak temperature was held for 3 hours. The weights of the burned samples were approx. $50 \mathrm{~g}$.

The burned material was investigated for its phase composition by powder XRD. The measurement conditions were the same as for the XRD analysis of the insoluble residue.

\section{RESULTS AND DISCUSSION}

\subsection{Petrographic character of studied limestones}

The studied limestones can be classified as biomicrite limestone (41) or wackstone to wackstone/ packstone (33) (Table 1). According to the carbonate rock classification (based on the proportions of their main constituents - i.e. calcite (carbonate), quartz (cryptocrystalline quartz - chalcedony and other forms of $\mathrm{SiO}_{2}$ ), and clay minerals (42)), the studied samples can be characterised as limestone or siliceous limestones (Table 1).

Carbonates are the most abundant rock-forming mineral (80-90 wt. \%) in the studied rocks (Table 1). Among them, calcite predominates (Table 1), mostly in the form of micritic matrix (55-60 vol. \% of total carbonate content), and skeletal grains (fragmentary bioclasts) (25-35 vol. \% of total carbonate content); accompanied with subordinate sparite cement (10-15 vol. \% of total carbonate content). Except for subordinate sparite, this type of cement occurs in the form of fibrous "beef" calcite (Figure 5E).

Bioclasts were derived from the most abundant and well-preserved shells of tentaculites (Figures 5A, 6A-E), followed by cephalopods, gastropods, ostracods (Figure 5C, D), crinoids, and trilobites (Figure 5B). A certain portion of the skeletal grains (15-25\% of their total content) could not be identified due to their fragmentary nature, which lessened any identification marks.

Dolomite crystals were only commonly observed in one of the studied specimens (HPV/I/3), whilst remained rare in the others. The zonal fabric of these crystals (compare Figure 7D, F) results from variation in the $\mathrm{MgO}$ content, which generally decreases to the rim of grains. Based on data from the chemical analyses processed by the MINLITH algorithm, the content of dolomite in the whole rock ranges from 1 to 2 wt. $\%$. 
TABLE 1. Results of qualitative and quantitative petrographic analyses of the studied limestones

\begin{tabular}{|c|c|c|c|c|}
\hline & HPV/I/1 & HPV/I/2 & HPV/I/3 & HPV/I/4 \\
\hline \multicolumn{5}{|c|}{$\begin{array}{c}\text { Content of carbonate and non-carbonate phases (wt. \% based on the determination } \\
\text { of insoluble residue by leaching off carbonates in acids) }\end{array}$} \\
\hline Carbonates & 90.13 & 90.36 & 82.75 & 80.03 \\
\hline Insoluble residue & 9.87 & 9.64 & 17.25 & 19.97 \\
\hline \multicolumn{5}{|c|}{$\begin{array}{l}\text { Content of calcite and dolomite in studied limestones (wt. \% from the total content of mineral phases } \\
\text { based on the wet silicate analysis data processed by the MINLITH) }(36,37)\end{array}$} \\
\hline Calcite & 88.97 & 87.17 & 80.18 & 79.73 \\
\hline Dolomite & 1.16 & 1.17 & 1.85 & 1.17 \\
\hline \multicolumn{5}{|c|}{ Proportion of basic forms of carbonates (vol. \% from total carbonate content) } \\
\hline Micrite & 55 & 55 & 60 & 60 \\
\hline Sparite & 10 & 15 & 15 & 15 \\
\hline Bioclasts & 35 & 30 & 25 & 25 \\
\hline \multicolumn{5}{|c|}{ Nature and proportion of bioclasts (vol. \% from total content of bioclasts) } \\
\hline Tentaculites & 30 & 30 & 40 & 35 \\
\hline Cephalopods & 10 & 10 & 10 & 15 \\
\hline Ostracods & 20 & 10 & 10 & 15 \\
\hline Crinoids & 10 & 5 & 10 & 5 \\
\hline Brachiopods & - & 5 & - & 5 \\
\hline Trilobites & - & 5 & 5 & 5 \\
\hline Gastropods & 10 & 10 & 5 & 5 \\
\hline Non-identified & 20 & 25 & 20 & 15 \\
\hline
\end{tabular}

Content of mineral phases forming insoluble residue (wt. \% from the total content of mineral phases based on the wet silicate analysis data processed by the MINLITH algorithm) $(36,37)$

\begin{tabular}{|c|c|c|c|c|}
\hline Quartz & 5.32 & 5.45 & 10.08 & 12.36 \\
\hline Illite & 3.29 & 3.53 & 3.22 & 3.55 \\
\hline Kaolinite & 1.09 & 1.23 & 1.09 & 1.12 \\
\hline Chlorite & 0.19 & 0.18 & 0.44 & 0.51 \\
\hline K-feldspar & 0.40 & 0.47 & 0.66 & 0.78 \\
\hline Plagioclase (albite) & 0.25 & 0.26 & 0.32 & 0.27 \\
\hline Rutile & 0.06 & 0.06 & 0.06 & 0.09 \\
\hline Fe-oxihydroxides & 0.15 & 0.14 & 0.15 & 0.23 \\
\hline Other minerals & 0.34 & 0.34 & 0.42 & 1.36 \\
\hline
\end{tabular}

\begin{tabular}{|c|c|c|c|c|}
\hline \multicolumn{5}{|c|}{ Petrographic classification of studied limestones } \\
\hline Folk (40) & Biomicrite limestone & Biomicrite limestone & Biomicrite limestone & Biomicrite limestone \\
\hline Dunham (33) & Wackestone & Wackestone & Wackestone/packstone & Wackestone/packstone \\
\hline Konta (41) & Limestone & Limestone & Siliceous limestone & Siliceous limestone \\
\hline
\end{tabular}

Non-carbonate phases contribute to $10-20 \mathrm{wt} . \%$ of solid matter in the studied limestones (Table 1, Figure 8) based upon weighing of products of leaching off carbonates in acidic solutions. Both of the acids used for extraction of the insoluble residue are very effective in terms of dissolution of carbonates present.

According to the powder XRD study, the insoluble residue is composed of quartz (cryptocrystalline quartz - chalcedony), phyllosilicates (chlorite and clay minerals such as illite, kaolinite), and feldspars. Due to the dominance of quartz (chalcedony) and some clay minerals (illite and kaolinite), some minor and/or accessory phases were hardly detectable from the XRD data. The dominant forms of $\mathrm{SiO}_{2}$ were quartz grains (Figure 7A) and cryptocrystalline quartz - chalcedony (Figure 7C-F). Kaolinite usually occurred in the form of larger detrital grains (Figure 7B, E); illite was either observed as small grains (Figure 7A, B, F) or as the filling of pressure 

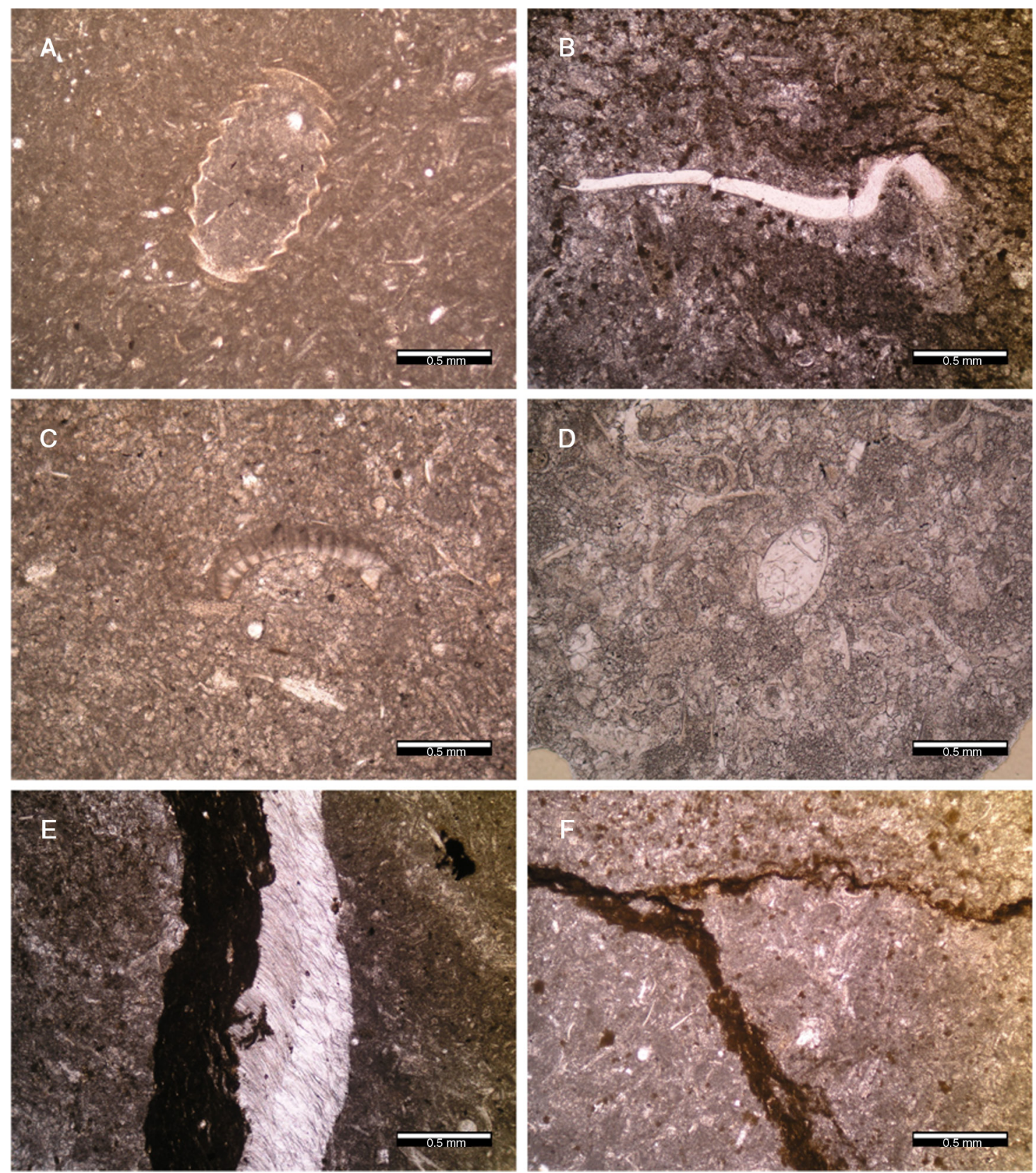

FiguRE 5. Characteristic microscopic features of the studied limestones as observed by optical microscopy of thin sections. Finegrained micritic matrix rich in microfossils - cross-section of tentaculite Nowakia sp., sample HPV/I/1 (A); cross-section of unspecified trilobite fragment in coarser matrix with common clay minerals and opaque phases, sample HPV/I/4 (B); fragment of ostracod, sample HPV/I/3 (C); cross-section of articulated ostracod filled by sparite cement, sample HPV/I/3, (D); "beef" calcite formed around the pressure solution seams, sample HPV/1/4 (E); pressure solution seams filled with clay minerals, sample HPV/1/4 (F).

solution seams (Figure 7E). From the accessory phases, apatite, biotite, and muscovite were the most common, but traces of zircon, barite, titanite, and pyrite (Figure 7C-F) were found, as well. SEM/EDS also allowed for the detection of some weathering features of phyllosilicates such as kaolinization and/ or chloritization (Figure 7B, E, F).

According to the MINLITH algorithm, quartz makes up the most abundant non-carbonate phase in the studied rocks, ranging from 5 to $12 \mathrm{wt} . \%$ in the whole rock (Table 1 ) and 54 to $62 \mathrm{wt} . \%$ in the insoluble residue. Illite can be considered as a minor phase, with its content in the whole rock ranging from 3 to $4 \mathrm{wt}$. \%, but it is still the second most common non-carbonate phase making up $16-32$ wt. \% of the insoluble residue. Kaolinite is less abundant, contributing to about $1 \mathrm{wt} . \%$ in the whole rock (5-11 wt. \% in the insoluble residue). 

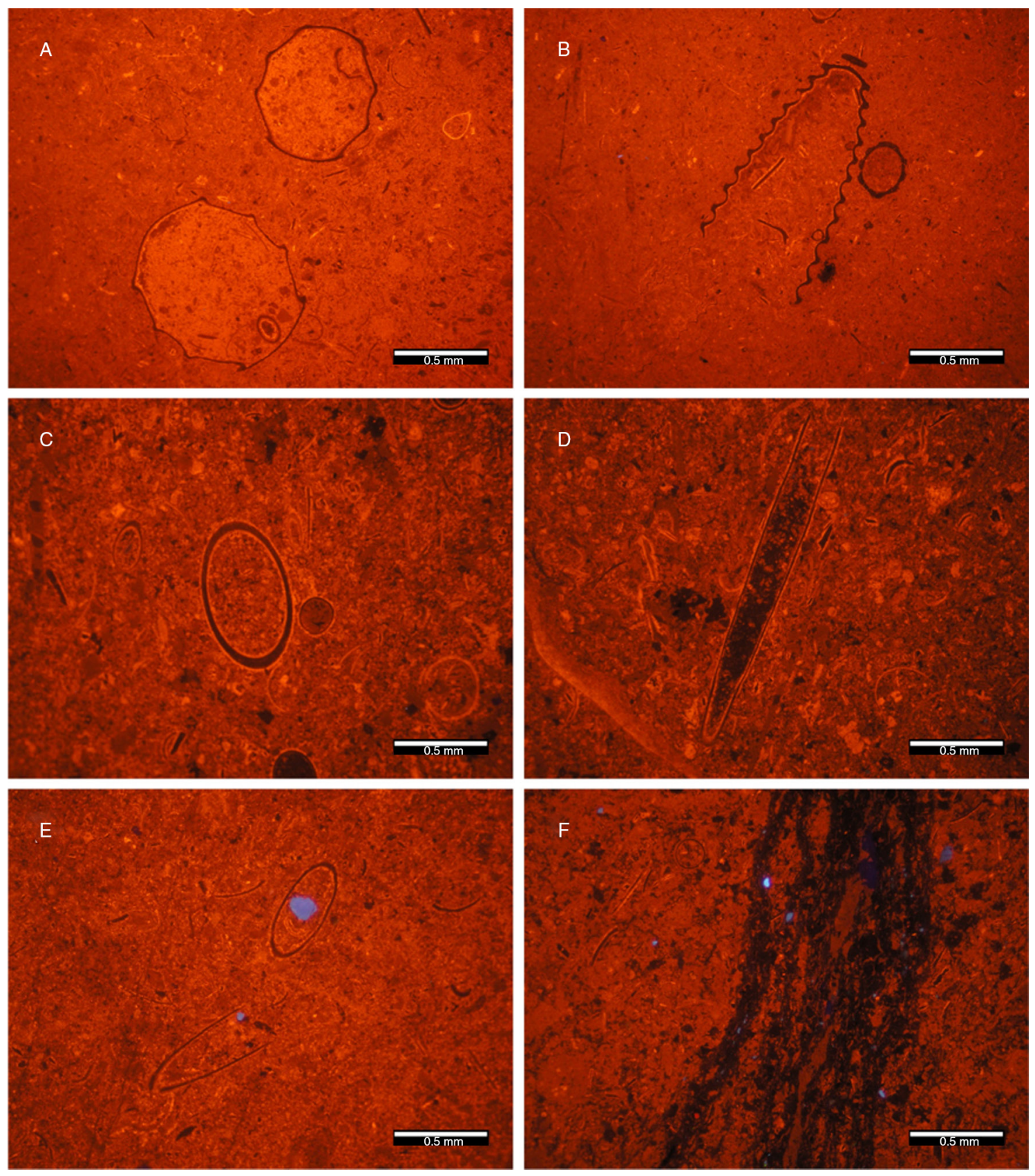

FIGURE 6. Microphotographs of the studied limestones as seen using CL. Cross-section through a couple of Nowakia sp. tentaculite in micritic matrix (dominant calcite shows orange CL), sample HPV/I/1 (A, B); cross-section through tentaculite Styliolina cf., sample HPV/I/4 (C, D); K-feldspar grain (blue CL) inside a shell of tentaculite Styliolina cf., sample HPV/4 (E); grains of K- and/or Na-feldspars (blue CL) in the pressure solution seams, sample HPV/3 (F).

Feldspars, chlorite, and rutile can be considered as accessory phases, with their content below $1 \mathrm{wt}$. \% in the whole rock. Regarding feldspars, K-feldspar is more abundant than plagioclase (albite) (Table 1). The presence of both feldspars was confirmed by CL and SEM/EDS microscopy as well (Figures 6E, F, 7A, F).

Non-carbonate minerals are preferentially randomly distributed in the matrix (Figure 9), but can be present within bioclasts as well (Figures 6E, 7C, D), as confirmed by microscopic study (specifically SEM/EDS) (Figure 7A-F). A higher concentration of these phases can be observed in the stylolites and/or in the pressure solution seams (Figure $5 \mathrm{E}, \mathrm{F})$. Along with the clay-size fraction (mostly clay minerals, but also finely dispersed amorphous quartz (chalcedony) cemented spaces between carbonates) detected by XRD, also partly extractable from X-ray imaging of polished thin sections in 

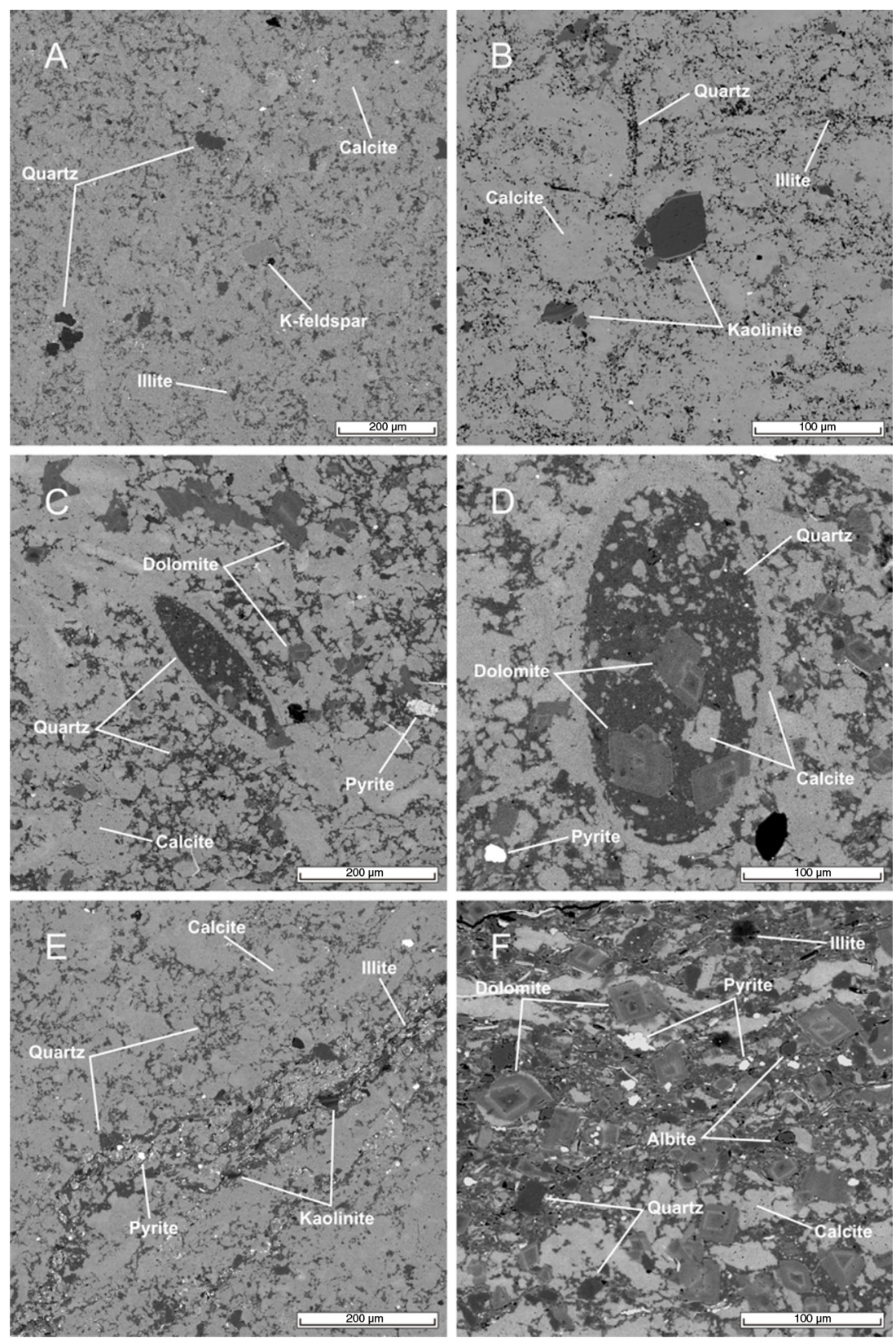

FIGURE 7. SEM-BSE microphotographs of polished thin sections documenting the characteristic phenomena in the studied limestones. Dominant calcite (micritic matrix) with clay minerals (prevalent illite), a few larger domains of quartz grains, and very few larger (silt-size) clasts of K-feldspar, sample HPV/I/1 (A); Calcite (micritic matrix) forming clusters separated with quartz (cryptocrystalline quartz - chalcedony) rich rims, relatively abundant clay minerals are represented by both illite and kaolinite, sample HPV/I/2 (B); Coarser-grained microfabric with calcite (micritic matrix) and dolomite grains (probably sparitic), quartz (chalcedony) makes up the common filling of interparticle spaces, pyrite makes an accessory phase, sample HPV/I/3 (C); Detail showing character of zonal dolomite grains occurring in quartz (chalcedony) filling of microfossil, sample HPV/I/3 (D); Micritic calcite-dominated matrix with interstitial quartz (chalcedony) filling, and pressure solution seams, rich in clay minerals (illite and kaolinite), accompanied with some accessory pyrite, sample HPV/I/4 (E); Domain of sparitic dolomite-rich domain with frequent non-carbonate minerals (clay minerals, silt size feldspars and quartz). Note that pyrite again makes up a common accessory phase, sample HPV/I/3 (F).

SEM/EDS (Figure 9); the silt-size fraction can be observed in the optical microscope with $\mathrm{CL}$ (Figure 6F). These later non-carbonate grains are dominated by clastic crystalline quartz (low $\alpha$-quartz), generally with no undulatory extinction, and minor feldspars.

\subsection{Geochemistry of studied limestones and their hydraulicity}

According to the results of wet-silicate analyses (Table 2), the studied limestones exhibit $\mathrm{CaO}$ content in the range of $44-50 \mathrm{wt} . \%$, which corresponds 


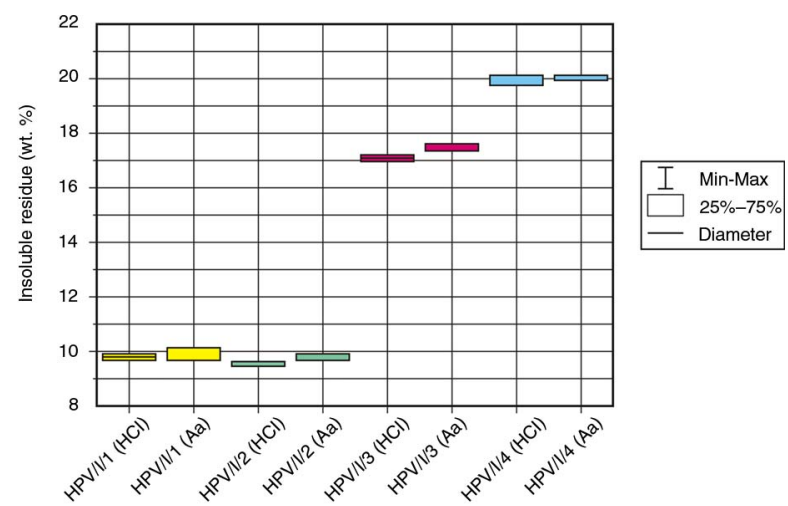

FIGURE 8. Percentage of insoluble residue in the samples of the studied limestones prepared by leaching off carbonates using hydrochloric acid $(\mathrm{HCl})$ and/or acetic acid (Aa); all data in wt. \%. to total carbonate content of 80-90 wt. \% (Table 1). A very low content of $\mathrm{MgO}$ (approx. 0.7 wt. $\%$ in 3 of the studied samples, 1.3 wt. $\%$ in 1 specimen) indicates a negligible dolomitic component, as confirmed by the CL study, which corresponds to the results of microscopic analyses (see above). The $\mathrm{Al}_{2} \mathrm{O}_{3}$ content can be attributed to both clay minerals/phyllosilicates (illite, kaolinite, and/or chlorite) and/or feldspars. As the content of alkalis is very low (specifically that of sodium, which does not exceed 0.07 wt. \%), one can assume that present feldspars are dominated by K-feldspar, whilst clay minerals are dominated by illite, which was also confirmed by microscopic analyses.

The quality of a raw material for the production of NHL is primarily governed by the presence and

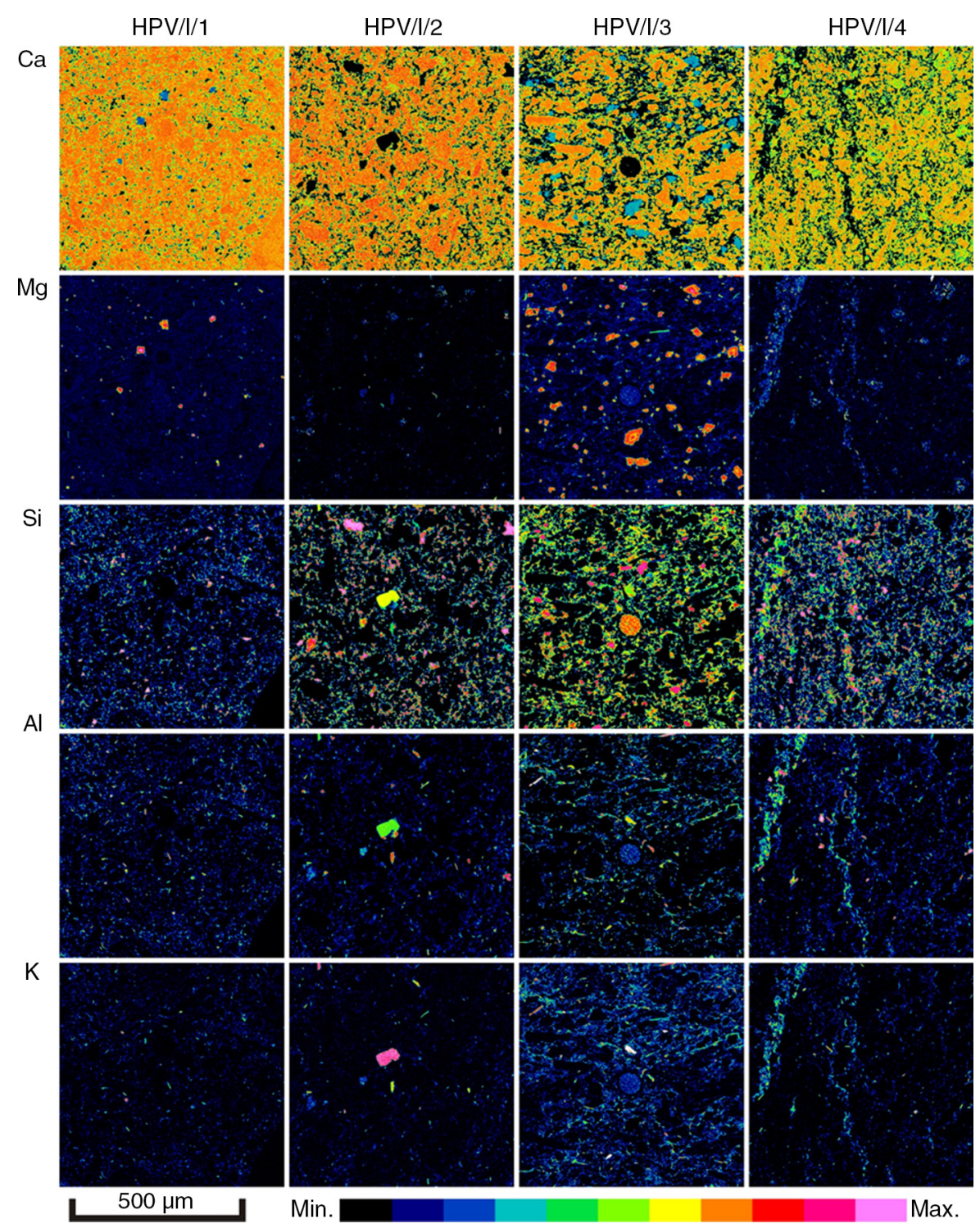

FIGURE 9. Distribution of the principal elements $(\mathrm{Ca}, \mathrm{Mg}, \mathrm{Si}, \mathrm{Al}, \mathrm{K})$ in the studied unburned limestones based on the XRD mapping performed by SEM/EDS. Based on these data, the spatial distribution of rock-forming minerals is highly homogeneous. 
TABLE 2. Chemistry of the studied limestone

\begin{tabular}{lcccc}
\hline & HPV/I/1 & HPV/I/2 & HPV/I/3 & HPV/I/4 \\
\hline $\mathrm{SiO}_{2}$ & 6.70 & 6.48 & 13.94 & 15.76 \\
$\mathrm{TiO}_{2}$ & 0.06 & 0.06 & 0.06 & 0.09 \\
$\mathrm{Al}_{2} \mathrm{O}_{3}$ & 1.23 & 1.26 & 1.29 & 1.62 \\
$\mathrm{Fe}_{2} \mathrm{O}_{3 \text { (tot) }}$ & 0.45 & 0.43 & 0.44 & 0.75 \\
$\mathrm{MnO}$ & 0.05 & 0.06 & 0.03 & 0.03 \\
$\mathrm{MgO}$ & 0.77 & 0.78 & 1.23 & 0.78 \\
$\mathrm{CaO}$ & 50.01 & 49.76 & 44.84 & 43.97 \\
$\mathrm{Na} 2 \mathrm{O}$ & 0.03 & 0.03 & 0.07 & 0.02 \\
$\mathrm{~K}_{2} \mathrm{O}$ & 0.37 & 0.35 & 0.35 & 0.44 \\
$\mathrm{P}_{2} \mathrm{O}_{5}$ & 0.05 & 0.08 & 0.06 & 0.05 \\
$\mathrm{H}_{2} \mathrm{O}^{+}$ & 0.12 & 0.10 & 0.12 & 0.18 \\
$\mathrm{H}_{2} \mathrm{O}^{-}$ & 1.20 & 1.17 & 1.18 & 1.35 \\
$\mathrm{CO}_{2}$ & 38.54 & 38.90 & 35.54 & 34.36 \\
$\Sigma$ & 99.79 & 99.60 & 99.55 & 99.57 \\
\hline
\end{tabular}

amount of non-carbonate minerals, specifically of quartz and clay minerals that contribute $\mathrm{SiO}_{2}$ and/ or $\mathrm{Al}_{2} \mathrm{O}_{3}(39,40,43)$, which is necessary for the formation of calcium silicates and aluminates (44). According to the results of wet silicate analyses, and from them the computed HI and CI, the studied limestones are represented by both feebly hydraulic members (samples HPV/I/1 and HPV/I/2), and additionally by eminently hydraulic members (samples HPV/I/3 and HPV/I/4) (Table 3).

\subsection{Phase composition of burned material and effect of peak temperature}

As expected from the study of the mineralogical and geochemical characteristics of the raw materials, the newly formed phases during burning are those typically found in the systems dominated by the presence of $\mathrm{CaO}-\mathrm{SiO}_{2}-\mathrm{Al}_{2} \mathrm{O}_{3}(\mathrm{C}-\mathrm{S}-\mathrm{A})$.

The phase composition of burned Dvorce-Prokop Limestones is dominated by free-lime $(\mathrm{CaO}-\mathrm{C})$ and/ or portlandite $\left(\mathrm{Ca}(\mathrm{OH})_{2}-\mathrm{CH}\right)$, larnite-belite (bicalcium silicate $\left.2 \mathrm{CaO} . \mathrm{SiO}_{2}-\mathrm{C}_{2} \mathrm{~S}\right)$, as well as quartz and other forms of $\mathrm{SiO}_{2}(\mathrm{~S})$ (Figures 10A-D, 11). Whilst the first two phases represent newly formed ones, the presence of quartz and other phases of $\mathrm{SiO}_{2}$ can be attributed to either unreacted silica from the original rock, or to the products of transformation of original minerals during their thermal decomposition $\left(\mathrm{SiO}_{2}\right.$ as the product of transformation of phyllosilicates above $\sim 1000{ }^{\circ} \mathrm{C}$ ).

Along with these dominant phases, some less abundant, but still clearly detectable newly formed phases were detected by powder XRD: gehlenite (2 $\left.\mathrm{CaO} . \mathrm{Al}_{2} \mathrm{O}_{3} \cdot \mathrm{SiO}_{2}-\mathrm{C}_{2} \mathrm{AS}\right)$, brownmillerite $(4 \mathrm{CaO}$. $\left.\mathrm{Al}_{2} \mathrm{O}_{3} \cdot \mathrm{Fe}_{2} \mathrm{O}_{3}-\mathrm{C}_{4} \mathrm{AF}\right)$, wollastonite $\left(\mathrm{CaO} . \mathrm{SiO}_{2}-\mathrm{CS}\right)$, calcium aluminate $\left(\mathrm{CaO} \cdot \mathrm{Al}_{2} \mathrm{O}_{3}-\mathrm{CA}\right)$, and spurrite $\left(5 \mathrm{CaO} .2 \mathrm{SiO}_{2} \cdot \mathrm{CO}_{2}-\mathrm{C}_{5} \mathrm{~S}_{2}\right)$.

The presence of the above mentioned phases and their mutual proportions vary depending on the composition of the raw material, maximum temperature reached during burning, and the granulometry of the experimental batch (Table 4).

The most favourable conditions for the formation of larnite-belite, the principal phase of the burned material, together with gehlenite and/or brownmillerite took place when the burning temperature exceeded $1100{ }^{\circ} \mathrm{C}$ (Table 4). On the other hand, freelime is more common in the temperature range of $850-1050^{\circ} \mathrm{C}$ (Table 4). Wollastonite is mostly present in specimens subjected to the peak burning temperature of $1000-1200^{\circ} \mathrm{C}$ (Table 4).

Calcium aluminate, and occasionally also the $\mathrm{Al}_{2} \mathrm{O}_{3}$-rich and $\mathrm{Fe}_{2} \mathrm{O}_{3}$-rich phases, are probably transitional phases that occur in the temperature range of $850-1000{ }^{\circ} \mathrm{C}$, but disappear at higher temperatures, which are involved in the formation of other phases $(45,46)$. Spurrite occurs as a minor phase, being a product of the reaction between calcium silicates and carbonate $(11,47)$. This phase is conventionally stable in the temperature range of $900-1100^{\circ} \mathrm{C}$ (48). For the studied samples, spurrite was found in the batch of all finely-ground experimental samples, and in samples HPV/I/3 and HPVI/4 of the coarselyground experimental batch (Table 4). The greatest amount of spurrite was found in specimens burned at the same temperatures, as noted by Glasser (48). However, in some samples (HPV/I/3 and HPVI/4) spurrite was also found in specimens burned at temperatures of $1200^{\circ} \mathrm{C}$. This result is probably caused by specific conditions in the laboratory furnace, where this phase remains stable due to a high concentration of $\mathrm{CO}_{2}$ and sufficient amount of calcium silicates.

TABLE 3. Classification of hydraulicity of the studied limestones based on their chemistry. $\mathrm{HI}=$ hydraulic index, $\mathrm{CI}=$ cementation index

\begin{tabular}{lcccc}
\hline & HPV/I/1 & HPV/I/2 & HPV/I/3 & HPV/I/4 \\
\hline HI (Spalding (38)) & 0.16 & 0.16 & 0.34 & 0.40 \\
& Feebly hydraulic & Feebly hydraulic & Eminently hydraulic & Eminently hydraulic \\
CI (Eckel (39)) & 0.40 & 0.39 & 0.87 & 1.03 \\
& Feebly hydraulic & Feebly hydraulic & Eminently hydraulic & Eminently hydraulic \\
\hline
\end{tabular}



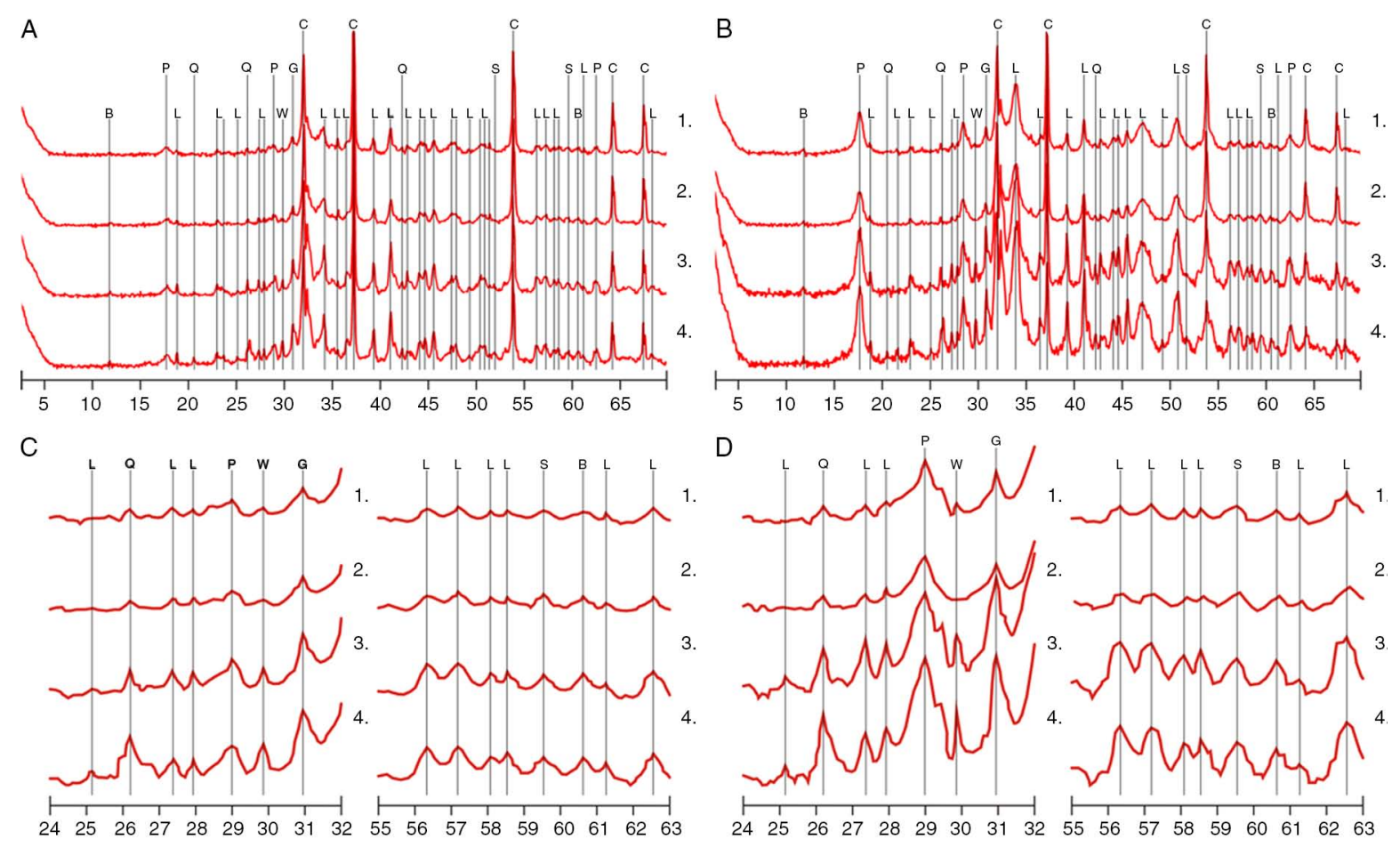

\footnotetext{
Legend: L - larnite-belite, C - free-lime, P - portlandite, Q - quartz and $\mathrm{SiO}_{2}$ phases, B - brownmillerite, G - gehlenite, W - wollastonite, S - spurrite

Figure 10. Complete XRD patterns (A, B) and XRD patterns in detail (C, D) of the samples burned at $1200{ }^{\circ} \mathrm{C}$ with the marked phases (HPV/I/1 - 1, HPV/I/2 - 2, HPV/I/3 - 3 and HPV/I/4 - 4). Both finely-ground batch $(\mathrm{A}, \mathrm{C})$ and coarsely-ground batch $(\mathrm{B}, \mathrm{D})$ are shown.
}

\subsection{Effect of peak temperature}

Along with the composition of the raw material, the burning temperature is the most important factor influencing the phase composition of the burned product (45). As can be seen from the XRD data (Figure 10A-D), as well as from the dependence of phase composition - burning temperature relationship (Figure 11), most of the hydraulic phases were formed in the temperature range of $1000-1200{ }^{\circ} \mathrm{C}$, during which the quartz content simultaneously dropped (Table 4). This observation specifically concerns those specimens with lower amounts of noncarbonate phases (specimens HPV/1 and HPV/2) that show very low quartz content within specimens burned above $1050-1100^{\circ} \mathrm{C}$. Practically, this means that for limestones containing about $10 \%$ of noncarbonate phases, a burning temperature of about $1100{ }^{\circ} \mathrm{C}$ should be sufficient for the formation of all major hydraulic phases. The highest amount of larnite-belite was formed in samples burned at the peak temperature of $1200{ }^{\circ} \mathrm{C}$, both in the finely- and coarsely-ground experimental batches (Figure 11 and Table 4). The amount of portlandite did not significantly change with an increase of temperature (Figure 11 and Table 4). The presence of this phase can be attributed to the reaction of free-lime with atmospheric moisture, as the burned specimens were cooled down under normal atmospheric conditions within the laboratory (R.H. was about $40 \%$ ).

\subsection{Effect of the grain size of experimental batches on the formation of new phases}

The granulometry of the burned raw material seems to be another factor specifically influencing the amounts of newly-formed hydraulic phases. As can been seen from the percentage of larnite-belite formed in the finely-and coarsely-ground experimental batches (Figure 11), the later batch shows a visibly higher proportion of this phase (Table 4). It is assumed that with respect to the finely-ground and homogeneous character of the microfabric of all studied limestones, the coarsely-ground experimental batch is characterised by the presence of grains that represent aggregates of all principal mineral phases that are in mutual contact during burning; thus having favourable conditions to react together to form larnite-belite and the other hydraulic phases when being burned.

On the contrary, the finely-ground experimental batch was probably ground to such a level that most 
$\mathrm{HPV} / / / 1$ (finely-ground batch)
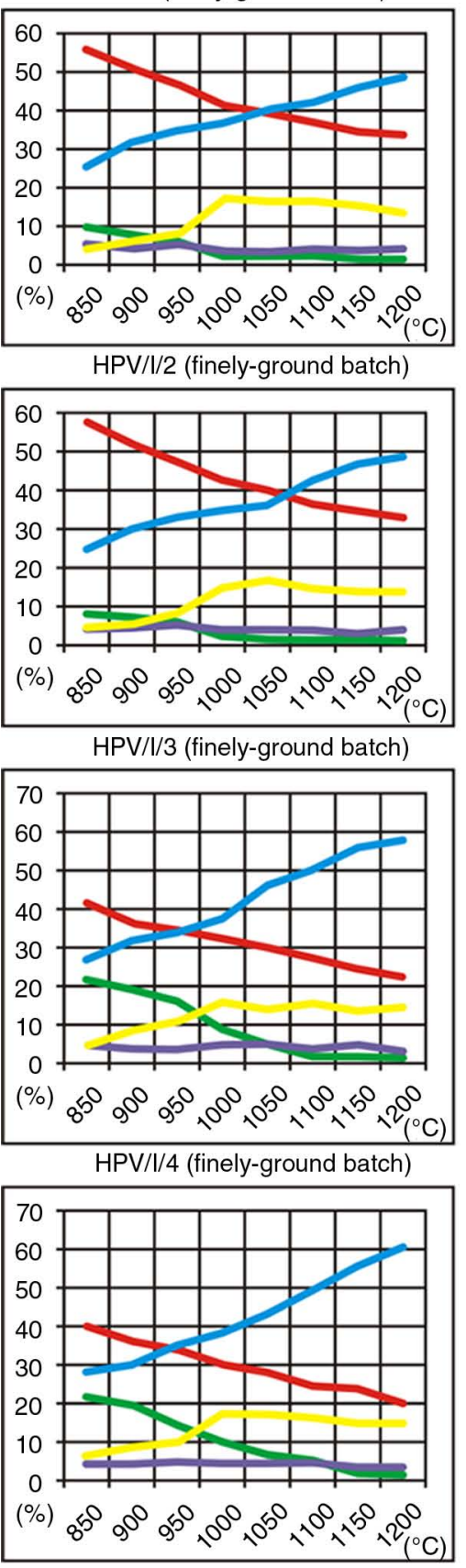

Larnite-belite

Quartz and $\mathrm{SiO}_{2}$ phases
HPV/I/1 (coarsely-ground batch)

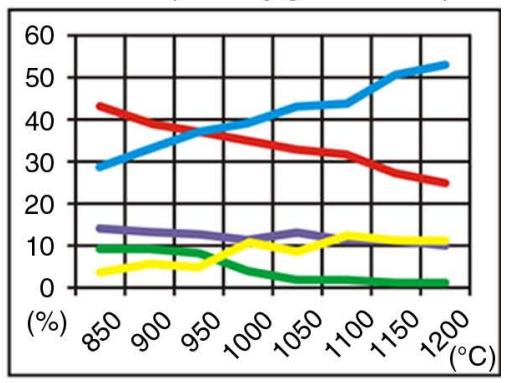

HPVI//2 (coarsely-ground batch)

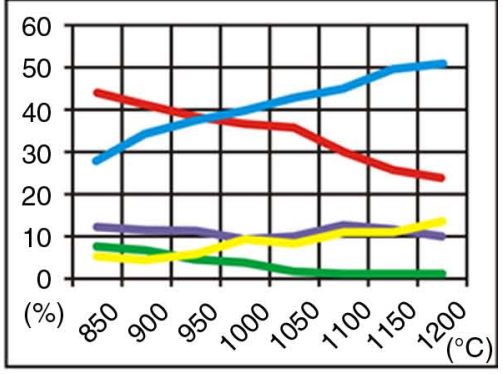

HPV/I/3 (coarsely-ground batch)

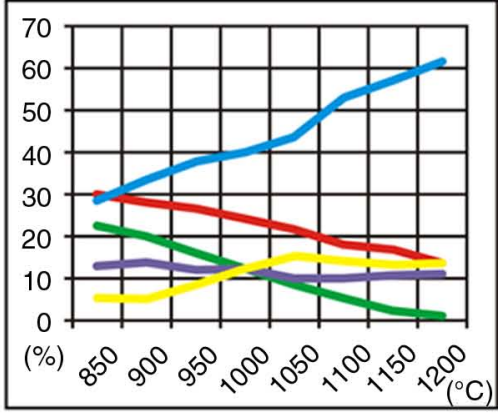

$\mathrm{HPV} / / / 4$ (coarsely-ground batch)

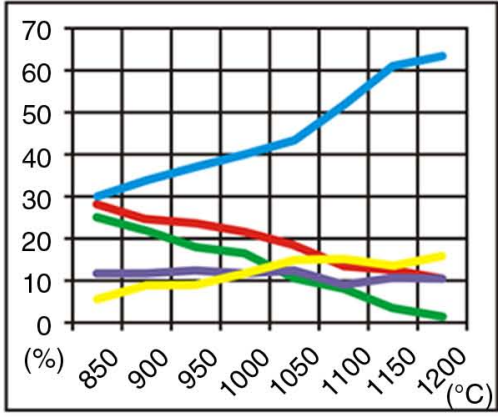

Free-lime $\longrightarrow$ Portlandite

Other phases

FIGURE 11. Relative (semi-quantitative) percentages of: larnite-belite, free-lime, portlandite, quartz and $\mathrm{SiO}_{2}$ phases, and other phases formed during burning at $850^{\circ} \mathrm{C}-1200^{\circ} \mathrm{C}$. Both finely-ground batch and coarsely-ground batch are shown.

of the present mineral grains (e.g., carbonates) were liberated, and thus it was more difficult to achieve the necessary reaction between the carbonate and non-carbonate phases. However, this observation is preliminary and requires further experimental evaluation, which is beyond the scope of current paper.

\section{CONCLUSIONS}

A set of limestones coming from one stratigraphic position (Dvorce-Prokop Limestone, Lower Devonian, Prague Basin, Bohemian Massif, Czech Republic) and exhibiting significant variation in 
TABLE 4. Relative (semi-quantitative) phase composition of products burned in the range of temperatures of $850-1200^{\circ} \mathrm{C}$. Both finely- and coarsely-ground batches are shown. Legend: $\mathrm{L}$ - larnite-belite, $\mathrm{C}$ - free-lime, $\mathrm{Q}$ - quartz and $\mathrm{SiO}_{2}$ phases, $\mathrm{P}$ - portlandite, $\mathrm{B}$ - brownmillerite, $\mathrm{G}$ - gehlenite, $\mathrm{W}$ - wollastonite, $\mathrm{H}$ - calcium aluminate $\mathrm{CA}, \mathrm{S}$ - spurrite

\begin{tabular}{|c|c|c|c|c|c|c|c|c|c|c|}
\hline \multicolumn{11}{|c|}{ HPV/I/1 finely-ground batch } \\
\hline Temperature & $\mathbf{L}$ & $\mathbf{C}$ & $\mathbf{Q}$ & $\mathbf{P}$ & B & G & $\mathbf{W}$ & $\mathbf{A}$ & $\mathbf{H}$ & $\mathbf{S}$ \\
\hline $850^{\circ} \mathrm{C}$ & 26 & 55 & 10 & 5 & - & - & - & 1 & 3 & - \\
\hline $900{ }^{\circ} \mathrm{C}$ & 32 & 50 & 8 & 4 & - & - & - & 2 & 4 & - \\
\hline $950{ }^{\circ} \mathrm{C}$ & 35 & 46 & 6 & 5 & - & 1 & - & 1 & 3 & 3 \\
\hline $1000^{\circ} \mathrm{C}$ & 37 & 41 & 2 & 3 & 3 & 3 & 4 & 1 & 2 & 4 \\
\hline $1050^{\circ} \mathrm{C}$ & 40 & 39 & 2 & 3 & 4 & 4 & 5 & - & - & 3 \\
\hline $1100^{\circ} \mathrm{C}$ & 42 & 36 & 2 & 4 & 4 & 5 & 5 & - & - & 2 \\
\hline $1150{ }^{\circ} \mathrm{C}$ & 46 & 34 & 1 & 4 & 5 & 5 & 4 & - & - & 1 \\
\hline $1200^{\circ} \mathrm{C}$ & 49 & 33 & 1 & 4 & 4 & 4 & 5 & - & - & - \\
\hline \multicolumn{11}{|c|}{ HPV/I/1 coarsely-ground batch } \\
\hline Temperature & $\mathbf{L}$ & $\mathbf{C}$ & $\mathbf{Q}$ & $\mathbf{P}$ & B & G & $\mathbf{W}$ & $\mathbf{A}$ & $\mathbf{H}$ & $\mathbf{S}$ \\
\hline $850^{\circ} \mathrm{C}$ & 29 & 43 & 10 & 14 & - & - & - & 2 & 2 & - \\
\hline $900^{\circ} \mathrm{C}$ & 33 & 39 & 9 & 13 & - & - & - & 2 & 4 & - \\
\hline $950^{\circ} \mathrm{C}$ & 37 & 37 & 8 & 13 & - & 1 & - & 1 & 3 & - \\
\hline $1000{ }^{\circ} \mathrm{C}$ & 39 & 35 & 4 & 11 & 2 & 4 & 3 & 1 & 1 & - \\
\hline $1050^{\circ} \mathrm{C}$ & 43 & 33 & 2 & 13 & 2 & 4 & 3 & - & - & - \\
\hline $1100^{\circ} \mathrm{C}$ & 44 & 31 & 2 & 11 & 4 & 5 & 3 & - & - & - \\
\hline $1150^{\circ} \mathrm{C}$ & 50 & 27 & 1 & 11 & 3 & 4 & 4 & - & - & - \\
\hline $1200^{\circ} \mathrm{C}$ & 53 & 25 & 1 & 10 & 3 & 4 & 4 & - & - & - \\
\hline
\end{tabular}

\begin{tabular}{lcccccccccc}
\hline \multicolumn{10}{c}{ HPV/I/2 finely-ground batch } \\
\hline Temperature & L & C & Q & P & B & G & W & A & H & S \\
\hline $850{ }^{\circ} \mathrm{C}$ & 26 & 57 & 8 & 4 & - & - & - & 2 & 3 & - \\
$900^{\circ} \mathrm{C}$ & 30 & 52 & 7 & 5 & - & - & - & 2 & 4 & - \\
$950{ }^{\circ} \mathrm{C}$ & 33 & 47 & 6 & 5 & - & 1 & 1 & 2 & 3 & 2 \\
$1000^{\circ} \mathrm{C}$ & 35 & 43 & 3 & 4 & 3 & 4 & 3 & 1 & 1 & 3 \\
$1050{ }^{\circ} \mathrm{C}$ & 37 & 40 & 2 & 4 & 4 & 5 & 5 & - & - & 3 \\
$1100{ }^{\circ} \mathrm{C}$ & 43 & 37 & 1 & 4 & 5 & 5 & 4 & - & - & 1 \\
$1150{ }^{\circ} \mathrm{C}$ & 47 & 35 & 1 & 3 & 4 & 5 & 5 & - & - & - \\
$1200{ }^{\circ} \mathrm{C}$ & 49 & 32 & 1 & 4 & 5 & 4 & 5 & - & - & - \\
\hline
\end{tabular}

HPV/I/2 coarsely-ground batch

\begin{tabular}{lcccccccccc}
\hline Temperature & L & C & Q & P & B & G & W & A & H & S \\
\hline $850{ }^{\circ} \mathrm{C}$ & 28 & 45 & 8 & 13 & - & - & - & 2 & 4 & - \\
$900{ }^{\circ} \mathrm{C}$ & 34 & 42 & 7 & 12 & - & - & - & 2 & 3 & - \\
$950{ }^{\circ} \mathrm{C}$ & 38 & 39 & 5 & 12 & - & 1 & 1 & 1 & 3 & - \\
$1000{ }^{\circ} \mathrm{C}$ & 40 & 37 & 4 & 9 & 3 & 2 & 3 & 1 & 1 & - \\
$1050{ }^{\circ} \mathrm{C}$ & 43 & 36 & 2 & 10 & 3 & 3 & 3 & - & - & - \\
$1100{ }^{\circ} \mathrm{C}$ & 45 & 30 & 1 & 13 & 4 & 4 & 3 & - & - & - \\
$1150{ }^{\circ} \mathrm{C}$ & 50 & 26 & 1 & 12 & 4 & 3 & 4 & - & - & - \\
$1200{ }^{\circ} \mathrm{C}$ & 51 & 24 & 1 & 10 & 5 & 4 & 5 & - & - & - \\
\hline \multicolumn{7}{c}{} & $\mathbf{H P V} / \mathbf{I} / 3$ finely-ground batch & & & \\
\hline Temperature & $\mathbf{L}$ & $\mathbf{C}$ & $\mathbf{Q}$ & $\mathbf{P}$ & $\mathbf{B}$ & $\mathbf{G}$ & $\mathbf{W}$ & $\mathbf{A}$ & $\mathbf{H}$ & $\mathbf{S}$ \\
\hline $850{ }^{\circ} \mathrm{C}$ & 26 & 42 & 22 & 5 & - & - & - & 2 & 3 & - \\
$900{ }^{\circ} \mathrm{C}$ & 31 & 37 & 19 & 4 & - & - & - & 3 & 4 & 2 \\
\hline
\end{tabular}

TABle 4. (Continued)

\begin{tabular}{|c|c|c|c|c|c|c|c|c|c|c|}
\hline \multicolumn{11}{|c|}{ HPV/I/3 finely-ground batch } \\
\hline Temperature & $\mathbf{L}$ & $\mathrm{C}$ & $\mathbf{Q}$ & $\mathbf{P}$ & B & G & $\mathbf{W}$ & $\mathbf{A}$ & $\mathbf{H}$ & $\mathbf{S}$ \\
\hline $950^{\circ} \mathrm{C}$ & 34 & 35 & 16 & 4 & - & 1 & 1 & 2 & 3 & 4 \\
\hline $1000{ }^{\circ} \mathrm{C}$ & 37 & 33 & 9 & 5 & 3 & 4 & 4 & 1 & 1 & 3 \\
\hline $1050^{\circ} \mathrm{C}$ & 46 & 30 & 5 & 5 & 4 & 4 & 5 & - & - & 1 \\
\hline $1100{ }^{\circ} \mathrm{C}$ & 50 & 28 & 2 & 4 & 5 & 5 & 4 & - & - & 2 \\
\hline $1150^{\circ} \mathrm{C}$ & 55 & 25 & 1 & 5 & 4 & 4 & 5 & - & - & 1 \\
\hline $1200^{\circ} \mathrm{C}$ & 58 & 23 & 1 & 3 & 5 & 5 & 4 & - & - & 1 \\
\hline \multicolumn{11}{|c|}{ HPV/I/3 coarsely-ground batch } \\
\hline Temperature & $\mathbf{L}$ & $\mathrm{C}$ & $\mathbf{Q}$ & $\mathbf{P}$ & B & G & $\mathbf{W}$ & $\mathbf{A}$ & $\mathbf{H}$ & $\mathbf{S}$ \\
\hline $850^{\circ} \mathrm{C}$ & 28 & 31 & 22 & 13 & - & - & - & 3 & 3 & - \\
\hline $900{ }^{\circ} \mathrm{C}$ & 34 & 27 & 20 & 14 & - & - & - & 2 & 2 & 1 \\
\hline $950^{\circ} \mathrm{C}$ & 38 & 26 & 16 & 12 & - & 1 & 1 & 2 & 1 & 3 \\
\hline $1000^{\circ} \mathrm{C}$ & 40 & 24 & 12 & 12 & 2 & 3 & 3 & 1 & 1 & 2 \\
\hline $1050{ }^{\circ} \mathrm{C}$ & 44 & 22 & 9 & 10 & 4 & 5 & 4 & - & - & 2 \\
\hline $1100{ }^{\circ} \mathrm{C}$ & 53 & 18 & 5 & 10 & 4 & 4 & 5 & - & - & 1 \\
\hline $1150^{\circ} \mathrm{C}$ & 57 & 17 & 2 & 11 & 4 & 5 & 4 & - & - & - \\
\hline $1200^{\circ} \mathrm{C}$ & 61 & 14 & 1 & 10 & 5 & 4 & 5 & - & - & - \\
\hline \multicolumn{11}{|c|}{ HPV/I/4 finely-ground batch } \\
\hline Temperature & $\mathbf{L}$ & $\mathbf{C}$ & $\mathbf{Q}$ & $\mathbf{P}$ & B & G & $\mathbf{W}$ & $\mathbf{A}$ & $\mathbf{H}$ & $\mathbf{S}$ \\
\hline $850^{\circ} \mathrm{C}$ & 28 & 40 & 22 & 4 & - & - & - & 3 & 3 & - \\
\hline $900^{\circ} \mathrm{C}$ & 31 & 36 & 19 & 5 & - & - & - & 3 & 4 & 2 \\
\hline $950{ }^{\circ} \mathrm{C}$ & 36 & 34 & 15 & 5 & - & 1 & 1 & 2 & 3 & 3 \\
\hline $1000{ }^{\circ} \mathrm{C}$ & 39 & 30 & 10 & 4 & 2 & 4 & 4 & 2 & 1 & 4 \\
\hline $1050^{\circ} \mathrm{C}$ & 44 & 28 & 7 & 4 & 2 & 5 & 4 & 1 & 1 & 4 \\
\hline $1100^{\circ} \mathrm{C}$ & 50 & 25 & 5 & 4 & 5 & 4 & 5 & - & - & 2 \\
\hline $1150{ }^{\circ} \mathrm{C}$ & 56 & 24 & 2 & 3 & 4 & 5 & 4 & - & - & 2 \\
\hline $1200^{\circ} \mathrm{C}$ & 61 & 20 & 1 & 3 & 4 & 5 & 5 & - & - & 1 \\
\hline \multicolumn{11}{|c|}{ HPV/I/4 coarsely-ground batch } \\
\hline Temperature & $\mathbf{L}$ & $\mathbf{C}$ & $\mathbf{Q}$ & $\mathbf{P}$ & B & $\mathbf{G}$ & $\mathbf{W}$ & $\mathbf{A}$ & $\mathbf{H}$ & $\mathbf{S}$ \\
\hline $850^{\circ} \mathrm{C}$ & 29 & 28 & 25 & 11 & - & - & - & 3 & 4 & - \\
\hline $900^{\circ} \mathrm{C}$ & 33 & 25 & 22 & 11 & - & - & - & 3 & 4 & 2 \\
\hline $950^{\circ} \mathrm{C}$ & 37 & 24 & 18 & 12 & - & 1 & 1 & 2 & 3 & 2 \\
\hline $1000{ }^{\circ} \mathrm{C}$ & 39 & 22 & 16 & 11 & 1 & 3 & 4 & 1 & 2 & 1 \\
\hline $1050^{\circ} \mathrm{C}$ & 44 & 19 & 10 & 12 & 3 & 4 & 4 & 1 & 1 & 2 \\
\hline $1100^{\circ} \mathrm{C}$ & 52 & 14 & 8 & 11 & 4 & 5 & 5 & - & - & 1 \\
\hline $1150^{\circ} \mathrm{C}$ & 61 & 12 & 3 & 10 & 4 & 4 & 5 & - & - & 1 \\
\hline $1200^{\circ} \mathrm{C}$ & 63 & 10 & 1 & 10 & 5 & 6 & 4 & - & - & 1 \\
\hline
\end{tabular}

composition (quantity of carbonates $80-90$ vol. \%, quartz 5-12 vol. \%, phyllosilicates - clay minerals 4-5 vol. \%) was burned under laboratory conditions at temperatures from 850 to $1200{ }^{\circ} \mathrm{C}$.

Due to the mineralogical and chemical compositions of the raw materials, the burned product was dominated by free-lime $(\mathrm{C})$ and/or portlandite $(\mathrm{CH})$, larnite-belite $\left(\mathrm{C}_{2} \mathrm{~S}\right)$, as well as quartz and other $\mathrm{SiO}_{2}$ phases (S). However, some minor admixtures of 
wollastonite $(\mathrm{CS})$, gehlenite $\left(\mathrm{C}_{2} \mathrm{AS}\right)$, brownmillerite $\left(\mathrm{C}_{4} \mathrm{AF}\right)$, calcium aluminate $(\mathrm{CA})$, and spurrite $\left(\mathrm{C}_{5} \mathrm{~S}_{2}\right)$ were detected as well. The presence of the hydraulic phases was not only affected by the composition of the raw materials and peak temperature reached during experimental burning, but also by the specific conditions during laboratory burning, as well as by the granulometry of the experimental batches. In this study, spurrite remained stable in specimens burned at temperatures of about $1200{ }^{\circ} \mathrm{C}$, which is attributed to the specific conditions in the laboratory furnace where this phase remains stable due to a high concentration of $\mathrm{CO}_{2}$.

For raw materials exhibiting only 10 vol. \% of non-carbonate phases (i.e., suitable for the production of feebly hydraulic lime), the peak burning temperature of about $1100{ }^{\circ} \mathrm{C}$ seems to be sufficient for the formation of all principal hydraulic phases. Raw materials with an eminently hydraulic character (i.e., containing about $20 \%$ of non-carbonate phases) require a burning temperature of about $1200{ }^{\circ} \mathrm{C}$ for the formation of the maximum amount of larnite-belite.

The amount of hydraulic phases formed during burning was also significantly affected by the granulometry of experimental batches. In the recent study, the amount of hydraulic phases was consistently higher in the coarsely-ground experimental batch (i.e., having grain size in the range of $1.25-3 \mathrm{~mm}$ ) than in the finely-ground experimental batch (grain size up to $200 \mu \mathrm{m}$ ). It is assumed that for the coarsely-ground experimental batch, the mineral phases present in the studied limestones remain in mutual contact during burning, and thus have favourable conditions to react together to form larnite-belite and others hydraulic phases. On the contrary, the finely-ground experimental batch was ground to such a fine level that most of the mineral grains present (e.g., carbonates having a micritic character) were liberated, and thus it was more difficult to achieve the necessary reaction between the carbonate and non-carbonate phases.

\section{ACKNOWLEDGEMENT}

This paper makes part of Petr Kozlovcev's Ph.D. study. Experimental part of the work has been financed by the research project No. 904314 "Influence of the mineralogical composition of raw material on phases formed during the burning of hydraulic lime and natural cement" from the Charles University Grant Agency.

\section{REFERENCES}

1. Hughes, D.C.; Sugden, D.B.; Jaglin, D.; Mucha, D. (2008) Calcination of Roman cement: A pilot study using cementstones from Whitby. Constr. Build. Mat. 22, 1446-1455. http://dx.doi.org/10.1016/j.conbuildmat.2007.04.003.
2. Juenger, M.C.G.; Winnefeld, F.; Provis, J.L.; Ideker, J.H. (2011) Advances in alternative cementitious binders. Cem. Concr. Res. 41, 1232-1243. http://dx.doi.org/10.1016/j. cemconres.2010.11.012.

3. Callebaut, K.; Elsen, J.; Van Balen, K.; Viaene, W. (2001) Nineteenth century hydraulic restoration mortars in the Saint Michael's Church (Leuven, Belgium). Natural hydraulic lime or cement? Cem. Concr. Res. 31, 397-403. http://dx.doi. org/10.1016/S0008-8846(00)00499-3.

4. Elert, K.; Rodriguez-Navarro, C.; Sebastian Pardo, E.; Hansen, E.; Cazalla, O. (2002) Lime mortars for the conservation of historic buildings. Stud. Cons. 47, 62-75.

5. Van Balen, K.; Papayianni, I.; Van Hees, R.; Binda, L.; Waldum, A. (2005) Introduction to requirements for and functions and properties of repair mortars. Mat. Struct. 38, 781-785. http://dx.doi.org/10.1007/BF02479291.

6. Maravelaki-Kalaitzaki, P. (2007) Hydraulic lime mortars with siloxane for waterproofing historic masonry. Cem. Concr. Res. 37, 283-290. http://dx.doi.org/10.1016/j. cemconres.2006.11.007.

7. Moropoulou, A.; Polikreti, K. (2009) Principal Component Analysis in monument conservation: Three application examples. J. Cult. Herit. 10, 73-81. http://dx.doi.org/10.1016/ j.culher.2008.03.007.

8. Bianco, N.; Calia, A.; Denotarpietro, G.; Negro, P. (2013) Laboratory assessment of the performance of new hydraulic mortars for restoration. Procedia Chem. 8, 20-27. http:// dx.doi.org/10.1016/j.proche.2013.03.004.

9. Gullota, D.; Goidanich, S.; Tedeschi, C.; Nijland, T.G.; Toniolo, L. (2013) Commercial NHL-containing mortars for the preservation of historical architecture. Part 1: Compositional and mechanical characterisation. Constr. Build. Mat. 38, 31-42. http://dx.doi.org/10.1016/j. conbuildmat.2012.08.029.

10. Moropoulou, A.; Bakolas, A.; Moundoulas, P.; Aggelakopoulou, E.; Anagnostopoulou, S. (2013) Optimization of compatible restoration mortars for the earthquake protection of Hagia Sophia. J. Cult. Herit. 14, Suppl. e147-e152. http://dx.doi.org/10.1016/j. culher.2013.01.008

11. Hughes, D.C.; Jaglin, D.; Kozłowski, R.; Mucha, D. (2009) Roman cements - Belite cements calcined at low temperature. Cem. Concr. Res. 39, 77-89. http://dx.doi. org/10.1016/j.cemconres.2008.11.010.

12. Weber,J.; Gadermayr, N.;Kozłowski, R.; Mucha, D.; Hughes, D.; Jaglin, D.; Schwarz, W. (2007) Microstructure and mineral composition of Roman cements produced at defined calcination conditions. Mater. Character. 58, 1217-1228. http://dx.doi.org/10.1016/j.matchar.2007.04.025.

13. Kozłowski, R.; Hughes, D.; Weber, J. (2010) Roman cements: key materials of the built heritage of the 19th century. In: Boştenaru, D.; Přikryl, R.; Török, Á. (eds.) Materials, Technologies and Practice in Historic Heritage Structures. Springer, Dordrecht New York. 259-277.

14. Giavarini, C.; Ferretti, A.S.; Santarelli, M.L. (2006) Mechanical characteristics of Roman "opus caementicium". In: Kourkoulis, S.K. (ed.) Fracture and Failure of Natural Building Stones. Springer, Berlin. 107-120.

15. Přikryl, R.; Novotná, M.; Přikrylová, J.; Weishauptová, Z.; St’astná, A. (2011) Physical and mechanical properties of the repaired sandstone ashlars in the facing masonry of the Charles bridge in Prague (Czech Republic) and analytical study for the causes of its rapid decay. Environ. Earth Sci. 63, 1623-1639. http://dx.doi.org/10.1007/s12665010-0819-5.

16. Sabbioni, C.; Zappia, G.; Riontino, C.; Blanco-Varela, M.T.; Aguilera, J.; Puertas, F.; Van Balen, K.; Toumbakari, E.E. (2001) Atmospheric deterioration of ancient and modern hydraulic mortars. Atm. Environ. 35, 539-548. http://dx.doi.org/10.1016/S1352-2310(00)00310-1.

17. Oleson, J.P.; Brandon, C.; Cramer, S.M.; Cucitore, R.; Gotti, E.; Hohlfelder, R.L. (2004) The Romacons project: a contribution to the historical and engineering analysis of hydraulic concrete in roman maritime structures. Int. J. Nautic. Archaeol. 33, 199-229. http://dx.doi.org/10.1111/ j.1095-9270.2004.00020.x. 
18. Ingo, G.M.; Fragalà, I.; Bultrini, G.; Caro, T.; Riccucci, C.; Chiozzini, G. (2004) Thermal and microchemical investigation of Phoenician-Punic mortars used for lining cisterns at Tharros (western Sardinia, Italy). Thermochim. Acta 418, 53-60. http://dx.doi.org/10.1016/j.tca.2003.11.053.

19. Moropoulou, A.; Bakolas, A.; Anagnostopoulou, S. (2005) Composite materials in ancient structures. Cem. Concr. Comp., 27(2), 295-300.

20. Silva D.A.; Wenk, H.R : Monteiro, PJM (2005) Comparative investigation of mortars from Roman Colosseum and cistern. Thermochim. Acta 438, 35-40. http://dx.doi.org/10.1016/j. tca.2005.03.003

21. Velosa, A.L.; Coroado, J.; Veiga, M.R.; Rocha, F. (2007) Characterization of Roman mortars from Conímbriga with respect to their repair. Mater. Character. 58, 1208-1216. http://dx.doi.org/10.1016/j.matchar.2007.06.017.

22. Láník, J.; Cikrt, M. (2001) Two thousand years of the Czech lime and cement industries. Svaz výrobců cementu a vápna Čech, Moravy a Slezska, Výzkumný ústav maltovin Praha spol. s r. o., Praha (In Czech).

23. Chlupáč, I. (1988) The Devonian of Czechoslovakia and its stratigraphic significance. In: McMillian, N.J.; Embry, A.F.; Glass, D.J. (eds.) Devonian of the World, Canadian Society for Petroleum Geologists, Memoirs, 14. 481-497.

24. Chlupáč, I.; Havlíček, V.; Kříž, J.; Kukal, Z.; Storch, P. (1998) Palaeozoic of the Barrandian (Cambrian to Devonian). Czech Geological Survey, Prague, 183

25. Havlíček, V. (1981) Development of a linear sedimentary depression exemplified by the Prague Basin (Ordovician Middle Devonian, Barrandian, Central Bohemia). Sbor. geol. Véd, řada $G, 7-48$.

26. Chlupáč, I.; Brzobohatý, R.; Kovanda, J.; Stráník, Z. (2002) Geologická minulost Ceské republiky. Academia, Prague (in Czech).

27. Melichar, R. (2004) Tectonics of the Prague Synform: a hundred years of scientific discussion. Krystalinikum 30, 167-187.

28. Röhlich, P. (2007) Structure of the Prague Basin: The deformation diversity and its causes (the Czech Republic). Bull. Geosci. 82, 175-182.

29. Cháb, J. (1993) General problems of the TB (TepláBarrandian) Precambrian, Bohemian Massif, the Czech Republic. Věstník Č GÚ 68, 1-6.

30. Glasmacher, U.A.; Mann, U.; Wagner, G.A. (2002) Thermotectonic evolution of the Barrandian, Czech Republic, as revealed by apatite fission-track analysis. Tectonophysics 359, 381-402. http://dx.doi.org/10.1016/ S0040-1951(02)00538-3.

31. Krrižz, J. (1999) Geological monuments of Prague. Proterozoic and Lower Paleozoic. Czech Geological Survey, Prague, 278. (In Czech with English summary).

32. Chlupáč, I.; Kukal, Z. (1986) Reflexion of possible global Devonian events in the Barrandian area. C.S.S.R. Lecture Notes in Earth Sciences 8, 171-179.

33. Dunham, R.J. (1962) Classification of carbonate rocks according to depositional texture. In: Ham, W.E. (ed.)
Classification of carbonate rocks. $A A P G$, Memoir 1, $108-121$.

34. Přikryl, R.; Št’astná, A. (2010) Contribution of clayey-calcareous silicite to the mechanical properties of structural mortared rubble masonry of medieval Charles Bridge in Prague (Czech Republic). Eng. Geol. 115, 257-267. http:// dx.doi.org/10.1016/j.enggeo.2010.06.009.

35. Zeno, F. (1770) Beschreibung des bei Prag von dem Wissehrader Tore gelegenen Kalksteinbruches, mit seinen Seeversteinerungen und anderen Fossilien. N. physik. Belustigun. 2, 362-420.

36. Kirschenbaum, H. (1983) The classical chemical analysis of silicate rocks - the old and the new. Geological Survey Bulletin 1547, United States Government Printing Office, Washington.

37. Rosen, O.M.; Abbyasov, A.A.; Migdisov, A.A.; Yaroshevskii, A.A. (2000) MINLITH-A Program to Calculate the Normative Mineralogy of Sedimentary Rocks: The Reliability of Results Obtained for Deposits of Old Platforms. Geochem. Int. 38, 388-400.

38. Rosen, O.M.; Abbyasov, A.A.; Tipper, J.C. (2004) MINLITH-an experience-based algorithm for estimating the likely mineralogical compositions of sedimentary rocks from bulk chemical analyses. Comp. Geosci. 30, 647-661. http://dx.doi.org/10.1016/j.cageo.2004.03.011.

39. Spalding, F.P. (1898) Hydraulic cement. Its properties, testing, and use. $1^{\text {st }}$ ed., John Wiley \& Sons, New York

40. Eckel, E.C. (1928) Cements, Limes and Plasters: Their Materials, Manufacture, and Properties. $3^{\text {rd }}$ ed., John Wiley \& Sons, New York.

41. Folk, R.L. (1962) Spectral subdivision of limestone types. In: Ham W.E. (ed.) Classification of carbonate rocks. AAPG, Memoir 1, 62-84.

42. Konta, J. (1973) Quantitative system of residual rocks, sediments and volcanoclasic deposits. Universita Karlova, Praha. (In Czech)

43. Cowper, A.D. (1927) Lime and Lime Mortars. Building Research Station, HM Stationary Office, London.

44. Müller, Ch.J. (2005) Pozzolanic activity of natural clay minerals with respect to environmental geotechnics. Unpublished manuscript of Ph.D. thesis, Swiss Federal Institute of Technology, Zürich

45. Varas, M.J.; Alvarez de Buergo, M.; Fort, R. (2005) Natural cement as the precursor of Portland cement: Methodology for its identification. Cem. Concr. Res. 35, 2055-2065. http:// dx.doi.org/10.1016/j.cemconres.2004.10.045.

46. Elsen, J.; Mertens, G.; Van Balen, K. (2011) Raw materials used in ancient mortars from the Cathedral of Notre-Dame in Tournai (Belgium). Eur. J. Mineral. 23, 871-882. http:// dx.doi.org/10.1127/0935-1221/2011/0023-2139.

47. Bolio-Arceo, H.; Glasser, F.P. (1990) Formation of spurite, $\mathrm{Ca}_{5}\left(\mathrm{SiO}_{4}\right)_{2} \mathrm{CO}_{3}$. Cem. Concr. Res. 20, 301-307.

48. Glasser, F.P. (1973) The formation and thermal stability of spurite, $\mathrm{Ca}_{5}\left(\mathrm{SiO}_{4}\right)_{2} \mathrm{CO}_{3}$. Cem. Concr. Res. 3, 23-28. 